Sains Malaysiana 47(6)(2018): 1181-1187

http://dx.doi.org/10.17576/jsm-2018-4706-13

\title{
The Effect of Molecular Weight on the Surface and Permeation of Poly(L-lactic acid)-Poly(ethylene glycol) Membrane with Activated Carbon Filler
}

(Kesan Berat Molekul kepada Permukaan dan Ketelapan Membran Poli(l-asid laktik)-Poli(etilena glikol) dengan Pengisi Karbon Teraktif)

\author{
AFIFAH MUHAMAD SIDIK, RIZAFIZAH OTHAMAN \& FARAH HANNAN ANUAR*
}

\begin{abstract}
The use of biodegradable material in membrane technology will be a great solution in reducing non-biodegradable waste in the landfill. Membranes can often be useful as the recycle stream can usually be much cleaner than with other techniques. This article describes the preparation of poly(l-lactic acid)-poly(ethylene glycol) (PLLA-PEG) free standing flat sheet membranes with the presence of $5 \mathrm{wt} . \%$ activated carbon filler. PLLA-PEG crosslinked copolymer was synthesized using PLLA with different molecular weight PEG prepolymers i.e. 4000, 6000 and $10000 \mathrm{~g} / \mathrm{mol}$; and excess hexamethylene diisocyanate to form urethane linkages between the polymers. The reaction was carried out in a dichloromethanel tetrahydrofuran dual-solvents system. The PLLA-PEG/AC membranes in the weight ratio of 7:3:0.5 were then fabricated using solution casting and phase inversion techniques. The performance of the membranes was evaluated in terms of permeation water flux (PWF), palm oil mill effluent (POME) permeation, flux decline and contact angle. It was found that membrane containing $10000 \mathrm{~g} / \mathrm{mol}$ PEG has the highest total mean in PWF, POME flux and hydraulic permeability with values of $100.9 \mathrm{~L} / \mathrm{m}^{2} . h, 51.45 \mathrm{~L} / \mathrm{m}^{2} . h$ and $64.9^{\circ} ; 62.9^{\circ}$, respectively, due to high porosity. All of the membranes were more stable towards the flux decline of POME compared to water. At the same time, addition of AC to the copolymer considerably enhances the texture and porosity of the fabricated membranes.
\end{abstract}

Keywords: Activated carbon; membrane; palm oil mill effluent treatment; poly(ethylene glycol); poly(l-lactic acid)

ABSTRAK

Penggunaan bahan terbiodegradasi dalam bidang teknologi membran adalah kaedah yang baik dalam mengurangkan sisa tidak terbiodegradasi di tapak pelupusan. Membran sering digunakan kerana lazimnya aliran kitar semulanya adalah lebih bersih berbanding teknik lain. Kertas ini menerangkan penyediaan helaian membran menggunakan poli(l-asid laktik)-poli(etilena glikol) (PLLA-PEG) dengan kehadiran sebanyak 5 wt. \% pengisi karbon teraktif. Kopolimer PLLA-PEG disintesis menggunakan PLLA dan pra-polimer PEG dengan berat molekul yang berbeza iaitu 4000, 6000 dan $10000 \mathrm{~g} /$ mol; dan 1,6-heksimetilena diisosianat (HMDI) berlebihan untuk membentuk kumpulan berfungsi uretana antara polimer. Tindak balas tersebut dilakukan dalam sistem dwi-pelarut iaitu diklorometanaltetrahidrofurana.Membran PLLA-PEG/AC dalam nisbah berat 7:3:0.5 kemudiannya difabrikasi menggunakan kaedah penuangan larutan dan teknik penyongsangan fasa. Prestasi membran telah dinilai daripada segi ujian ketelapan air fluks (PWF), ketelapan efluen kilang minyak sawit (POME), penurunan fluks dan sudut sentuhan air. Didapati bahawa membran yang mengandungi PEG $10000 \mathrm{~g} /$ mol mempunyai jumlah min PWF yang tertinggi, fluks POME dan kebolehtelapan hidraulik yang tinggi masing-masing dengan nilai $100.9 \mathrm{~L} / \mathrm{m}^{2} . h, 51.45 \mathrm{~L} / \mathrm{m}^{2} . h$ dan $64.9^{\circ} ; 62.9^{\circ}$ disebabkan keliangan yang tinggi. Semua membran lebih stabil terhadap ujian fluks ketelapan POME berbanding dengan air. Pada masa yang sama, penambahan AC kepada kopolimer meningkatkan kualiti, tekstur dan keliangan membran.

Kata kunci: Karbon teraktif; membran;poli(l-asid laktik); poli(etilena glikol); rawatan efluen kilang minyak sawit

\section{INTRODUCTION}

Polyurethane is a class of polymers with various functional groups, allowing flexibility to tune the mechanical, chemical and thermal properties of a material. On the other hand, activated carbon powder is versatile filler due to the facility of surface modification and large surface area (Amaral et al.2014). In the study of activated carbon, Helena et al. (1991) stated that activated carbon is a black solid substance resembling granular or powdered charcoal (Helena et al. 1991). It is a processed carbon material with a highly developed porous structure and a large internal specific surface area which become the highly absorbed materials. The usage of activated carbon material seems to be useful for improving related applications and creating a new research field by exploring their potentials including in the waste-water treatment (Zainol et al. 2017).

Poly(lactic acid) (PLA) is a biodegradable and biobased polymer. It has the advantages of high modulus, high strength, thermoplasticity, transparency and biocompatibility, when compared to other biopolymers 
such as starch (Gui et al. 2012). However, PLA also has the drawbacks of inherent brittleness and poor toughness, which impede its wide application (Liu \& Zhang 2011; Meng et al. 2011; Rasal et al. 2010). Meanwhile, PEG shows hydrophilicity and biocompatibility (Desai \& Hubbell 1992; Ouchi et al. 1987) and it is soluble in water and an organic solvent (Lee et al. 1999). Other than that, it was found that PEG can increase the porosity and thickness of membrane (Saljoughi et al. 2010) and also an excellent plasticizer for PLA because of its good miscibility (Sheth et al. 1997). The elongation at break of PLA increases in the presence of PEG, but the impact resistance remains poor (Gui et al. 2012). Therefore, it is interesting to study the synthesis of biodegradable PLLAPEG multiblock copolymers to be used as membrane, in combination with activated carbon powder filler as absorbent.

An increase in molecular weight of PEG should result in the increase in pore number as well as pore size in membranes. Consecutively, membranes with PEG at higher molecular weight are reported to have higher permeation water flux (PWF) and higher hydraulic permeability due to the high porosity (Harun et al. 2012; Mohamad et al. 2013; Yunos et al. 2012). From previous study, PEG with a relatively low molecular weight was used as a pore-forming agent to enhance pure water flux and to reduce solute rejection of membranes. However, a further increment in the molecular weight of PEG resulted in reduction of pure water flux (PWF) and increasing solute rejection. Combined with the precipitation rates of different membrane-forming systems, the membrane formation mechanism describing PEG mobility was discussed extensively based on the length changes of PEG molecular chains and the affinity between PEG and casting solution (Zuo et al. 2008). Thus, for a better understanding of the role played by these components, the preparation of membrane comprised of PLLA-PEG copolymer with activated carbon filler and membrane performance based on the change of the length of PEG molecular chains will be discussed in this report.

\section{MATERIALS AND METHODS}

\section{MATERIALS}

Poly(l-lactic acid) (PLLA) was purchased from ESUN, China. Poly(ethylene glycol) (PEG) $\left(\mathrm{M}_{\mathrm{w}}=4000,6000\right.$ and $10000 \mathrm{~g} / \mathrm{mol})$, tin(II) 2-ethylhexanoate ( $\mathrm{Sn}(\mathrm{oct})_{2}$,
95\%), 1,6-hexamethylene diisocyanate (HMDI, 98\%) and activated carbon (AC) powder were purchased from SigmaAldrich (Malaysia). Analytical grade solvents including dichloromethane (DCM) and tetrahydrofuran (THF, 99\%) were purchased from Sigma-Aldrich (Malaysia). All other chemicals and reagents were of analytical grade. The chemicals were used as received. AC powder was sieved to the size of 45-63 $\mu \mathrm{m}$ prior to use. Distilled water was used in a coagulation bath for exchanging between solvent and non-solvent.

\section{PREPARATION METHODS}

Membranes comprised of poly(l-lactic acid)-poly(ethylene glycol) copolymer with activated carbon as filler (abbreviated as PLLA-PEG/AC) based on the weight ratio of 7:3:0.5 were prepared in this study, with a variation in molecular weight of PEG and a fixed amount of AC, as described in Table 1. The process involved three steps, where PLLA-PEG copolymer was first synthesized, followed by mixing with $\mathrm{AC}$ and subsequent fabrication of the membrane.

\section{PREPARATION OF PLLA-PEG/AC}

The PLLA-PEG copolymers were synthesized according to method developed by our group. In a $50 \mathrm{~mL}$ round bottom flask equipped with a magnetic bar. PLLA pellets ( $7.0 \mathrm{~g}$ ) were dissolved into DCM $(42 \mathrm{~mL})$, stirred at $45^{\circ} \mathrm{C}$ to dissolve and covered up with a greased flask stopper. At the same time, AC powder $(0.5 \mathrm{~g})$ was stirred in THF $(21 \mathrm{~mL})$ in a beaker covered with parafilm. After 2 h, PEG-4000 (3.0 g) is added into the flask that contain PLLA solution, followed by $\mathrm{Sn}(\mathrm{Oct})_{2}(36 \mathrm{mg})$ and HMDI $(0.7 \mathrm{~g})$. The solution was stirred for a period of $2 \mathrm{~h}$ at $45^{\circ} \mathrm{C}$. PLLA-PEG multiblock copolymer was formed after this stage of reaction. Then, the AC/THF mixture was added into the flask containing PLLA-PEG copolymer solution. AC residue from the beaker was rinsed with $21 \mathrm{~mL}$ of THF and copolymer/AC mixture was left to stir for $24 \mathrm{~h}$.

\section{FABRICATION OF PLLA-PEG/AC MEMBRANE}

Fabrication of membrane was carried out using the method reported by Norfarhana (2014). The PLLA-PEG/AC solution was casted onto a glass plate with thickness of $0.15 \mathrm{~mm}$ using a casting knife. The solvent was left to evaporate for $1 \mathrm{~min}$ before the plate was immersed into a coagulation bath. When an off-white solid membrane was formed, it

TABLE 1. The composition of PLLA-PEG/AC casting solution

\begin{tabular}{lcccc}
\hline Copolymer membranes & $\begin{array}{c}\text { Molecular weight of PEG } \\
\left(\mathrm{g} \mathrm{mol}^{-1}\right)\end{array}$ & $\begin{array}{c}\text { Weight of PEG } \\
(\mathrm{g})\end{array}$ & $\begin{array}{c}\text { Weight of PLLA } \\
(\mathrm{g})\end{array}$ & $\begin{array}{c}\text { Weight of AC } \\
(\mathrm{g})\end{array}$ \\
\hline PLLA-PEG4000/AC & 4000 & $3.0 \mathrm{~g}$ & $7.0 \mathrm{~g}$ & $0.5 \mathrm{~g}$ \\
PLLA-PEG6000/AC & 6000 & $3.0 \mathrm{~g}$ & $7.0 \mathrm{~g}$ & $0.5 \mathrm{~g}$ \\
PLLA-PEG1000/AC & 10000 & $3.0 \mathrm{~g}$ & $7.0 \mathrm{~g}$ & $0.5 \mathrm{~g}$ \\
\hline
\end{tabular}

PLLA:PEG:HMDI:Sn(Oct) ${ }_{2}$ weight ratio was kept at 7:3:7:0.036. The copolymer:solvents ratio for the membrane was 1:8.4 (w/v) 
was removed from coagulation bath and dried at ambient temperature. The average thickness of membrane after dried was 0.02-0.07 mm. These preparation methods were repeated using different molecular weight of PEG.

\section{CHARACTERIZATION}

Structural characterization of PLLA-PEG/AC membrane was performed by using attenuated total reflectance-Fourier transform infrared (ATR-FTIR) spectroscopy. ATR-FTIR spectra were recorded using Spectrum 400 Perkin Elmer GX Spectrometer in frequency range between 4000 and $650 \mathrm{~cm}^{-1}$. ATR-FTIR characterization was conducted to identify the functional groups present in the membrane as a result of the formation of PLLA-PEG copolymer. Static contact angles were measured using a model NRL C.A. Goniometer/100-00 to identify the properties of the membrane surface whether it is hydrophobic or hydrophilic membrane. All measurements were carried out with distilled water drops that had a total volume of $10 \mathrm{~mL}$ on the surface of each membrane coating on glass using a $1000 \mathrm{~mL}$ screw-top syringe. Permeation test was done to study the flux of the membrane by using dead end stirred cell model HP4750. Membrane was cut into size of $50 \mathrm{~mm}$ in diameter and then tested under nitrogen gas at pressure of 1,2 and 3 bar at ambient temperature. POME sample from final discharge pond from Malaysian Palm Oil Board (MPOB) at Labu, Negeri Sembilan was used in the experiment. Flux is calculated from (1):

$$
\mathrm{PWF}=\frac{Q}{A \times \Delta t}
$$

where $Q$ is the permeate volume (L); $A$ is the membrane area $\left(\mathrm{m}^{2}\right)$; and $\Delta t$ is the time $(\mathrm{h})$. The same process was repeated for 3 attempts.

\section{RESULTS AND DISCUSSION}

\section{SYNTHESIS OF PLLA-PEG COPOLYMER}

Urethane based copolymers are produced by reacting an isocyanate containing two or more isocyanate groups per molecule $\left(\mathrm{R}-(\mathrm{N}=\mathrm{C}=\mathrm{O})_{\mathrm{n}}\right)$ with a polymer containing on average two or more hydroxyl groups per molecule $\left(\mathrm{R}^{\prime}-(\mathrm{OH})_{\mathrm{n}}\right)$ in the presence of a catalyst. In this study, a polyurethane multiblock copolymer was prepared by the reaction that has taken place between PLLA, PEG and 1,6HMDI. The hydroxyl group (-OH) from PLLA and PEG was reacted with an isocyanate from HMDI to form urethane link and when this reaction is repeated, a multiblock copolymer of (P-HMDI) ${ }_{\mathrm{n}}$ type was obtained, where $\mathrm{P}$ can be either PLLA or PEG, since both prepolymers contain terminal $-\mathrm{OH}$ groups. This also means that the sequence of PLLA and PEG along the copolymer backbone is random. Summary of the synthesis of PLLA- PEG copolymers can be seen in Scheme 1.

\section{FUNCTIONAL GROUP ANALYSIS}

Figure 1 shows the FTIR spectra of PLLA-PEG/AC membranes obtained with different molecular weights of PEG and Table 2 compares the wavenumber $\left(\mathrm{cm}^{-1}\right)$ of each spectrum. The presence of urethane $-\mathrm{N}-\mathrm{H}$ functional group absorption band in the product spectrum can be served as evidence on the success of the reactions performed. Overall, there was no difference in the wavenumber from FTIR spectra of various PEG chain lengths. The spectra of the three membrane sample show similarity in the frequencies, where the strong band at $1755 \mathrm{~cm}^{-1}$ is assigned to the stretching vibration of ester carbonyl group $\mathrm{C}=\mathrm{O}$ of PLLA. Other than that, the band detected at $1105 \mathrm{~cm}^{-1}$ belongs to the characteristic -C-O-C- stretching vibration from PEG block, suggesting the presence of the two component
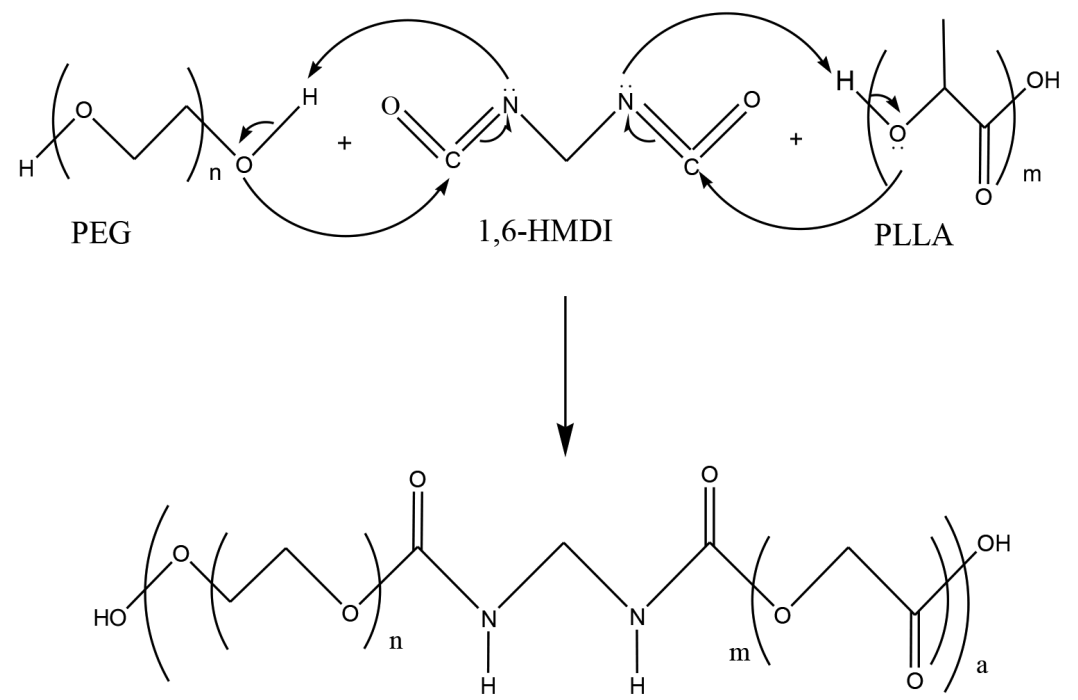

SCHEME 1. Reaction scheme between PEG, HMDI and PLLA to form polyurethane based PLLA-PEG multiblock copolymer 


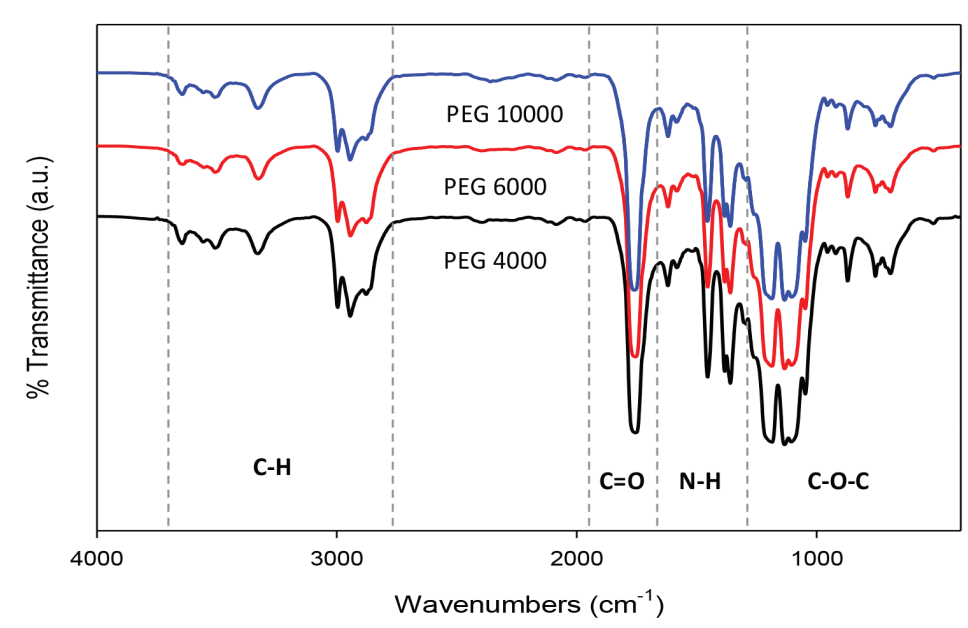

FIGURE 1. FTIR spectra of PLLA-PEG/AC by different molecular weight of PEG

TABLE 2. FTIR absorption bands of PLLA-PEG/AC with different molecular weight of PEG

\begin{tabular}{lcccc}
\hline Polymer / Wavenumber & $\mathrm{C}-\mathrm{H}\left(\mathrm{cm}^{-1}\right)$ & $\mathrm{C}=\mathrm{O}\left(\mathrm{cm}^{-1}\right)$ & $\mathrm{N}-\mathrm{H}\left(\mathrm{cm}^{-1}\right)$ & $\mathrm{C}-\mathrm{O}-\mathrm{C}\left(\mathrm{cm}^{-1}\right)$ \\
\hline PLLA-PEG4000/AC & 2996,2944 & 1755 & 1620 & 1186,1105 \\
PLLA-PEG6000/AC & 2995,2943 & 1756 & 1619 & 1186,1105 \\
PLLA-PEG10000/AC & 2996,2944 & 1760 & 1619 & 1186,1105 \\
\hline
\end{tabular}

blocks in the copolymer. Meanwhile, the bands at 2996 and $2944 \mathrm{~cm}^{-1}$ are due to the $\mathrm{C}-\mathrm{H}$ stretching vibration of $-\mathrm{CH}_{3}$ and - $\mathrm{CH}$ - groups. Furthermore, $-\mathrm{N}-\mathrm{H}$ bending is observed at frequencies of $1580 \mathrm{~cm}^{-1}$ and this indicates that the urethane functional group exists in the membrane of PLLA-PEG/AC (Wong \& Badri 2010). Moreover, the functional group isocyanate was reported to show a strong absorption at $2085 \mathrm{~cm}^{-1}$ (Hiltunen et al. 1997) and this band was not observed in the obtained spectra. Therefore, it can be said that HMDI molecules underwent complete reaction with PLLA and PEG prepolymers to form polyurethanes.

\section{PERFORMANCE TEST}

\section{EFFECT OF PEG MOLECULAR WEIGHT ON PERMEATION} AND REJECTION OF PURE WATER AND POME

Copolymer membranes prepared from PLLA-PEG copolymers with AC filler was employed in water permeability test. Figure 2 shows the membrane performance and membrane capability to resist their permeability by PWF testing unit. Permeation of distilled water in the pressure of 1 bar shows that membrane containing PEG10000 has higher flux with total mean of $100.9 \mathrm{~L} / \mathrm{m}^{2}$.h compared to membranes containing PEG6000 and PEG4000 which only 83.5 and $57.1 \mathrm{~L} / \mathrm{m}^{2} . h$, respectively. An increase in molecular weight of PEG segment from 4000 to 10000 leads to the increment in the water permeability of the PLLA-PEG/AC membrane. In general, PLLA has a relatively rigid structure that contributes in mechanical strength of a material, whereas PEG is a flexible polymer and has good mobility, owing to the low to moderate molecular weight used in this study. During the phase inversion process, PEG hydrophilic blocks were uniformly dispersed throughout the membrane, where it facilitates the diffusion of water molecules to the casted film in the coagulation bath, which consequently becomes a point for pore formation. When PEG molecular weight was increased from 4000 to 10000 , the pore size and pore number on membrane upper surface was increased (Zuo et al. 2008). More pores on membrane surface and the better interconnectivity inside membrane would contribute to enhancing pure water flux and reducing solute rejection (Kim \& Lee 1998). Correspondingly, fluctuations of PLLA-PEG4000/AC are significantly lower because of the presence of smaller molecular weight PEG. Fluctuations of PLLA-PEG6000/AC are only slightly lower than that of PLLA-PEG10000/AC. Zuo et al. (2008) found that in PEG-PVDF membrane system, as PEG molecular weight increased from 200 to 20000 , the macrovoids were developed initially and then were suppressed at transition point of PEG molecular weight of 6000 . However, this trend was not observed in our PLLA-PEG/AC membrane system. It is suggested that within the molecular weight range of our study, the thickness and porosity of PLLA$\mathrm{PEG} / \mathrm{AC}$ membranes increases with increasing molecular weight of PEG from 4000 to 10000 , which results in the increase in flux.

Figure 3 shows the membrane performance on the permeation of POME wastewater. Permeation of POME at the pressure of 3 bar shows that membrane fluxes was significantly improved by the increasing molecular weight of PEG. Membrane containing PEG10000 has higher flux with total mean of $51.45 \mathrm{~L} / \mathrm{m}^{2}$.h than membranes containing PEG6000 and PEG4000 with 48.9 and $25.01 \mathrm{~L} /$ 
$\mathrm{m}^{2}$.h, respectively. According to Bath et al. (2000), porous membrane surface and good interconnectivity inside a membrane indirectly enhance pure water flux and reduced solute rejection.

\section{Distilled water (1 Bar)}

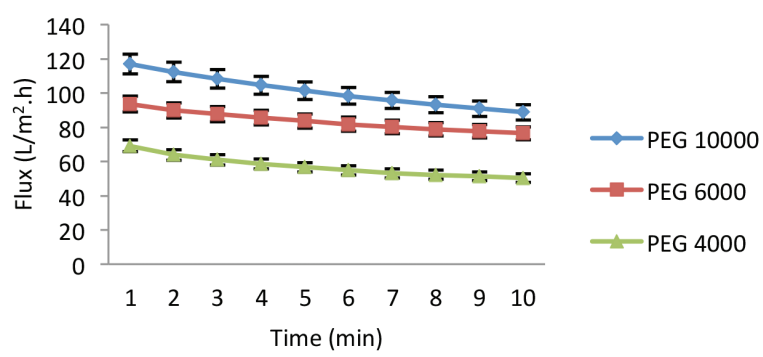

FIGURE 2. Total PWF from PLLA-PEG/AC membranes with different molecular weight of PEG

POME (3 Bar)

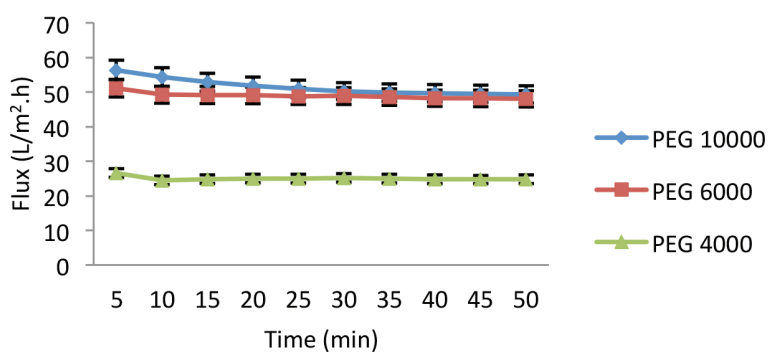

FIGURE 3. Total flux of POME from PLLA-PEG/AC membranes with different molecular weight of PEG

The palm oil mill effluent (POME) from Figure 4 is likely in dark brown colour before the ultrafiltration treatment. The result showed that ultrafiltration or permeation using PLLA-PEG/AC membranes changes the colour of POME from dark brown to light brown. The variation in the molecular weight of PEG in the copolymer gave remarkably different results on the POME treatment performances. Figure 5 shows the appearance of POME after treatment. The treatment was carried out three times for each membrane composition, using different membrane disc for every trial. POME filtered through PLLA-PEG4000/ AC (Figure 5(a)) appeared as clear light brown solution after the first two trials; whereas the POME obtained from filtration using PLLA-PEG6000/AC (Figure 5(b)) have lighter colour with consistent appearance for each trial. It can be seen that POME filtered using PLLA-PEG10000/AC (Figure 5(c)) shows the best improvement, with the lightest brown colour, nearly yellow, compared to the other two membranes. According to Shah and Singh (2004), colour can be further reduced by using activated carbon for more specific treatment system. The PLLA-PEG/AC membranes used contain a fixed amount of activated carbon, which is $5 \%(\mathrm{w} / \mathrm{w})$. Although the activated carbon facilitates in the discolouration of POME, the contribution of PEG is observable. The increment of PEG molecular weight gives better improvement in the discolouration of the POME.

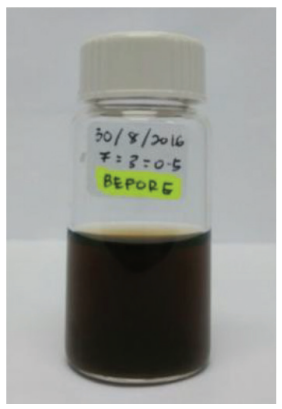

FIGURE 4. Palm oil mill effluent (POME) before treatment

(a)

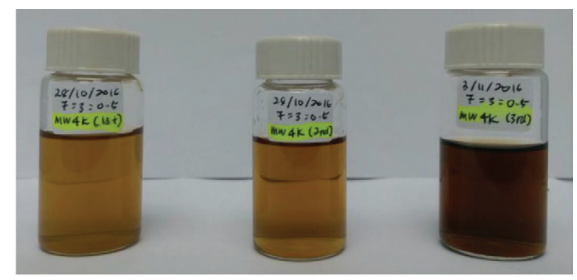

(b)

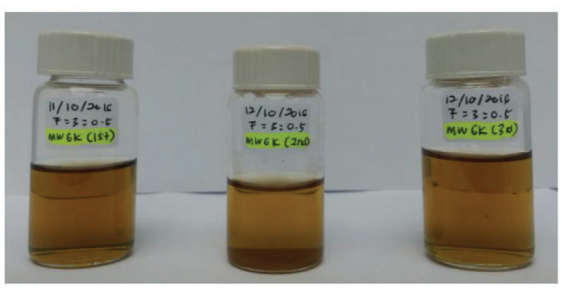

(c)

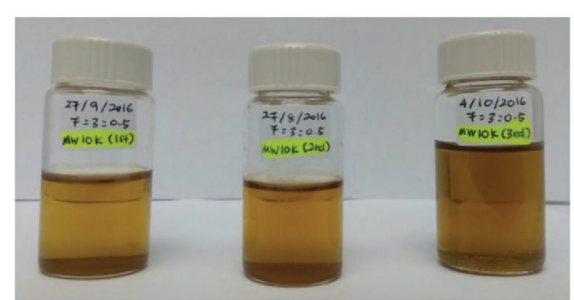

FIGURE 5. Palm oil mill effluent (POME) after ultrafiltration treatment with membrane PLLA-PEG/AC by using molecular weight of PEG (a) $4000 \mathrm{~g} / \mathrm{mol}$ (b) $6000 \mathrm{~g} / \mathrm{mol}$ (c) $10000 \mathrm{~g} / \mathrm{mol}$

\section{CONTACT ANGLE}

The hydrophobicity of each membrane was investigated by water contact angle measurement. Figure 6 shows the water contact angles of the upper and lower surface of the PLLA-PEG-AC with various molecular weight of PEG thin film. The result upper and lower surface is given to identify contrasting pores-forming on surface of membrane for hydrophobicity and hydrophilicity selection category. The contact angle of PLLA-PEG4000/AC shows the reading for the lower surface membrane only because during the measurement, the upper surface membrane absorbed the water just in a few seconds before the reading was taken. This could also mean that the surface of the membrane is highly hydrophilic, which causes the water contact angle 
Water contact angle measurement

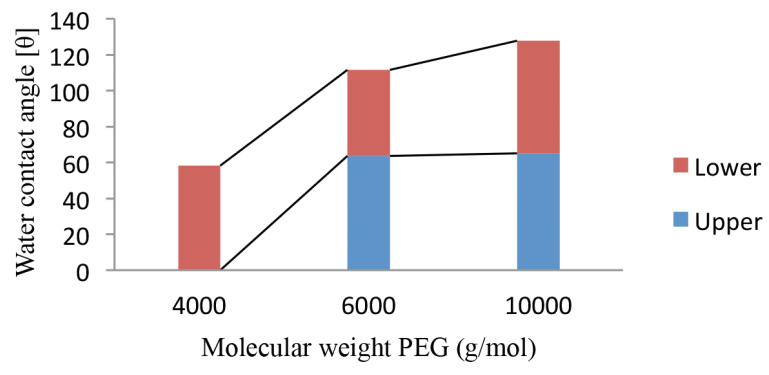

FIGURE 6. Water contact angles of the thin film of PLLA-PEG/ $\mathrm{AC}$ upper and lower side with different molecular weight of PEG

difficult to be measured. From the test, the lowest contact angle or in other words, the most hydrophilic membrane was shown by PLLA-PEG4000/AC with total angle upper and lower surface of $0^{\circ} ; 58.2^{\circ}$. The contact angles of PLLAPEG6000/AC with total angle $63.7^{\circ} ; 47.9^{\circ}$ are lower than that of PLLA-PEG10000/AC $64.9^{\circ} ; 62.9^{\circ}$, which indicate more hydrophilic characteristic than membrane containing PEG10000. The outcome relating to the Zuo et al. (2008) indicated that PEG with a relatively low molecular weight was used as a pore-forming agent to enhance pure water flux and reduce solute rejection of membranes, but PEG was used as a pore-reducing agent with a further increment of PEG molecular weight to result in pure water flux decreasing and solute rejection increasing.

\section{CONCLUSION}

The results of the present work suggested that the addition of PEG with different molecular weight could change the PLLA-PEG/AC membrane structure and properties. When PEG molecular weight was increased from 4000 to 6000 and 10000 , the improved PEG mobility because of a decrease in affinity between PEG and casting solutions was a leading factor. The performance of prepared membrane was evaluated in terms of PWF, POME permeation and contact angle. Membrane comprising highest molecular weight PEG (PLLA-PEG10000/AC) performed best in PWF test, indicating better performance results as the PEG molecular weight was increased. In the case of POME permeation, membrane containing PEG10000 and PEG6000 performed slightly the same, with the former being the best. The proposed PLLA-PEG/AC membrane system is a promising candidate to be implemented in POME treatment of waste water treatment. Further research that could be carried out includes investigating the effect of different ratio of activated carbon towards the properties of the membrane.

\section{ACKNOWLEDGEMENTS}

The authors would like to thank Universiti Kebangsaan Malaysia and the Ministry of Higher Education, Malaysia under the grant research of GUP-2016-060 and FRGS/2/2014/ SG06/UKM/02/1.

\section{REFERENCES}

Amaral, R.A.,Habert, A.C.\& Borges, C.P. 2014. Activated carbon polyurethane membrane for a model fuel desulfurization by pervaporation. Materials Letters 137: 468-470.

Bath, C., Goncalves, M.C., Pires, A.T.N., Roeder, J. \& Wolf, B.A. 2000. Effects of thermodynamic conditions during formation on their performance. Journal of Membrane Science 169: 287-299.

Desai, N.P. \& Hubbell, J.A. 1992. Surface physical interpenetrating networks of poly(ethylene-terephthalate) and poly(ethylene oxide) with biomedical applications. Macromolecules 25: 226-232.

Gui, Z., Xu, Y., Gao, Y., Lu, C. \& Cheng, S. 2012. Novel polyethylene glycol-based polyester-toughened polylactide. Materials Letters 71: 63-65.

Harun, Z., Ismail, N.F. \& Badarulzaman, N.A. 2012. Effect of $\mathrm{MgO}$ additive on microstructure of $\mathrm{Al}_{2} \mathrm{O}_{3}$. Advance Materials Research 488-489: 335-339.

Helena, J.,Andrzej, S. \& Jerzy, C. 1991 . Active Carbon. London: Ellis Horwood Ltd.

Hiltunen, K., Seppälä, J.V. \& Härkönen, M. 1997. Lactic acid based poly(ester-uretahanes): Use of hydroxyl terminated prepolymer in urethane synthesis. Journal of Polymer Science 63: 1091-1100

Kim, J.H. \& Lee, K.H.J. 1998. Effect of PEG additive on membrane formation by phase inversion. Membrane Science 138(2): 153-163

Lee, S.Y., Chin, I.J. \& Jung, J.S. 1999. Crystallization behavior of poly(L-lactide)-poly(ethylene glycol) multiblock copolymers. European Polymer Journal 35: 2147-2153.

Liu, H. \& Zhang, J. 2011. Research progress in toughening modification of poly(lactic acid). Journal Polymer Science Polymer Physics 49: 1051-1083.

Meng, B., Tao, J., Deng, J., Wu, Z. \& Yang, M. 2011. Toughening of polylactide with higher loading of nano-titania particles coated by poly( $\varepsilon$-caprolactone). Materials Letters 65: 729732 .

Mohamad, S.H., Idris, M.I., Abdullah, H.Z. \& Ismail, A.F. 2013.Short review of ultrafiltration of polymer membrane as a self-cleaning and antifouling in the wastewater system. In Proceedings of the 2nd International Conference on Sustainable Materials, Penang, Malaysia, 26-27 March.

Norfarhana, A.S. 2014. Penyediaan adunan getah asli terepoksida/ poli(vinil klorida)/sekam padi (ENR/PVC/SP) sebagai membran bagi rawatan air buangan. $\mathrm{PhD}$ Thesis, Universiti Kebangsaan Malaysia, Malaysia (Unpublished).

Ouchi, T., Yuyama, H. \& Vogl, O.J. 1987. Syntheses of 5-fluorouracil-terminated monomethqxypqly(ethylene glycol)S, their hydrolysis behavior, and their antitumor activities. Macromolecule Science Chemistry A24(9): 10111032.

Rasal, R.M., Janorkar, A.V. \& Hirt, D.E. 2010. Poly(lactic acid) modifications. Programe Polymer Science 35: 338-356.

Saljoughi, E., Amirilargani, M. \& Mohammadi, T. 2010. Effect of PEG additive and coagulation bath temperature on the morphology, permeability and thermal/chemical stability of asymmetric CA membranes. Desalination 262: 72-78.

Shah, R.S.S. \& Singh, P.K.K. 2004. Treatment of palm oil mill effluent (POME) using membrane technology. Symposium on Membrane Science and Technology. Universiti Teknologi Malaysia Institutional Repository. pp. 1-9.

Sheth, M., Kumar, R.A., Dave, V., Gross, R.A. \& Mccarthy, S.P. 1997. Biodegradable polymer blends of poly(lactic acid) and 
poly(ethylene glycol). Journal Application Polymer Science 66: $1495-1505$.

Wong, C.S. \& Badri, K.H. 2010. Sifat terma dan kerintangan api poliuretana berasaskan minyak isirung sawit dan minyak kacang soya. Sains Malaysiana 39(5): 775-784.

Yunos, M.Z., Harun, Z., Basri, H. \& Ismail, A.F. 2012. Effects of water as non-solvent additive on performance of polysulfone ultrafiltration membrane. Advance Material Research 488489: 46-50.

Zainol, M.M., Amin, N.A.S. \& Asmadi, M. 2017. Preparation and characterization of impregnated magnetic particles on oil palm frond activated carbon for metal ions removal. Sains Malaysiana 46(5): 773-782.

Zuo, D.Y., Xub, Y.Y., Xua, W.L. \& Zoua H.T. 2008. The influence of PEG molecular weight on morphologies and properties of PVDF asymmetric membranes. Chinese Journal of Polymer Science 26(4): 405-414.

Afifah Muhamad Sidik, Rizafizah Othaman \& Farah Hannan Anuar*

School of Chemical Sciences and Food Technology

Faculty of Science and Technology

Universiti Kebangsaan Malaysia

43600 UKM Bangi, Selangor Darul Ehsan

Malaysia
Rizafizah Othaman \& Farah Hannan Anuar*

Polymer Research Center

Faculty of Science and Technology

Universiti Kebangsaan Malaysia

43600 UKM, Bangi, Selangor Darul Ehsan

Malaysia

*Corresponding author; email: farahhannan@ukm.edu.my

Received: 16 September 2017

Accepted: 7 January 2018 